\author{
Maciej Kruszyna \\ dr hab. inż. prof. PWr \\ Politechnika Wrocławska, \\ Wydział Budownictwa Lądowego \\ i Wodnego, Katedra Dróg i Lotnisk \\ maciej.kruszyna@pwr.edu.pl
}

DOI: 10.35117/A_ENG_20_01_01

\title{
An (slightly) innovative vehicle for urban ground transport
}

\begin{abstract}
The article presents a proposal for constructing a vehicle for urban ground transport using a tram system (current consumption from the catenary, separate tracks), but with the option of leaving the track and using batteries or charging stations. This will allow for temporary or target extension of existing routes and for bringing large-scale rolling stock to densely built-up housing estates. Based on the review of modern solutions, the thesis was formulated that the development of an (slightly) innovative vehicle is "at your fingertips." The possibilities of introducing new rolling stock were shown on the example of Wroclaw. Nevertheless, the proposed solution may also be attractive to other, at least Polish cities.
\end{abstract}

Keywords: Tram; Trolleybus; Electric bus, Innovation

\section{Origin of the idea - conditions}

In large (as for Poland) cities it is necessary to prioritize the public transport network. Transport in the agglomeration (core city - surroundings) and the most important relationships in the city should be served by "main lines" [2] with a specific route and high standard of service. Standard of service is understood as both high commercial speed and transport capacity. In the latter aspect, the following are important: a large number of journeys (frequency) and the appropriate capacity of the rolling stock. In further considerations, the aspect of urban railways, such as metro, SKM, Light Rail, which constitute a separate travel segment, is omitted. The content of the article focuses on the segment of "urban surface transport" traditionally operated by trams, trolleybuses, or buses. Such a segment is exclusive to medium-sized cities, and also occurs in larger and largest cities as a supplement to urban railways. Ground vehicles have lower commercial speeds than light rail, although decent values can be obtained by separating (mostly horizontal) routes and prioritizing signaling. The advantage of this segment is very good accessibility and the ability to penetrate building areas.

Traditional means of transport such as trams, trolleybuses, and buses have undergone many changes in their history. Numerous innovations are introduced to the market, including hybrid vehicles with various forms of traction, propulsion, and surface. The dimensions of such vehicles are very diverse, but today it is no longer possible to clearly separate them: all trams are longer, and buses/trolleybuses are shorter. An overview of the latest solutions is given later in the article, while here the conditions for a vehicle in the segment of surface urban transport effective in the mainline system are formulated, taking into account the specificity of Polish cities, but against the background of solutions from Europe and beyond.

Well, a mainline vehicle must have a large capacity. The capacity is expressed in the number of passengers, but due to different standards regarding the filling of $1 \mathrm{~m}^{2}$ and different proportions between sitting and standing places, a comprehensive comparison of individual vehicles is difficult. To simplify the considerations, the length of vehicles is further operated, assuming that the longer the unit, the greater its capacity. Until recently, the condition of high 
capacity was met only by trams, whose multi-unit (and formerly multi-car) trains offered lengths of more than $30 \mathrm{~m}$, and even within $45 \mathrm{~m}$. Buses and articulated (three-axle) trolleybuses with lengths of $18 \mathrm{~m}$ clearly stood out in this ranking. Let us initially assume that the effective vehicle in the segment considered here should be longer than $18 \mathrm{~m}$.

Another aspect is the matter of propulsion (fuel). Electric vehicles are desirable. For example, the Act [5] provides in Article 35 that: "a local government unit, with the exception of communes and counties, the number of inhabitants of which does not exceed 50,000, ensures that the share of electric vehicles in the fleet of vehicles used in the office serving it is at least $30 \%$ of the number of vehicles in use". Obviously, due to the care of the urban environment, a higher proportion of electric vehicles is desirable. Some cities already reach $100 \%$. Low floor, numerous doors, large windows, air conditioning, and amenities such as USB chargers, information panels, a practical ticket system (e.g. "entry-exit" type) are elements that are already becoming a standard in public transport and as such do not require a wider comment here.

Systemic and financial conditions are also important. These first mean the dilemma of introducing/modifying new solutions to the existing ones. New/additional rolling stock other than the one used so far requires a number of investments (network, power supply, facilities, personnel). The coexistence of different solutions sometimes gives rise to technical problems (e.g. traction crossing). As regards financial conditions, the aspect of infrastructure development costs (routes, rolling stock, back-up facilities), which is significant in the light of the conditions of Polish cities, should be raised (see the report of ZGT TOR [4]). Therefore, in studies on the development of the urban transport system, one should take into account the complex conditions that determine the balance of costs and benefits. Choose the most effective concepts and those that fit into the current situation. In simplified terms, it is possible to adopt the postulate of the greatest possible use of the existing resources and the economical implementation of modifications (this will be developed further).

\section{Overview of the latest solutions and trends}

The article focuses on an attempt to indicate the optimal rolling stock (vehicle) for the rapid pace of the development of the collective ground transport network for Polish cities. The review of the latest solutions and trends is made in terms of the conditions formulated above.

First of all, it is worth mentioning the long buses: four-axle, three-part, and doublearticulated. These are not always purely electric vehicles. For example, in Metz, France, in 2013 the "Mettis" system was launched, based on semi-electric buses (the engine is a hybrid type), $23.8 \mathrm{~m}$ long, manufacturer: Van Hool, Belgium. Figure 1 shows such a bus on a dedicated route in the city center. One of the first long buses was Volvo's "Phileas" vehicle (first in Dutch Eindhoven, then in South Korea, Turkey, Israel), originally planned as an autonomous vehicle. Figure 2 shows the Metrobus Plileas in Istanbul. Many leading bus manufacturers offer similarly large units (Mercedes, Scania, ...). 


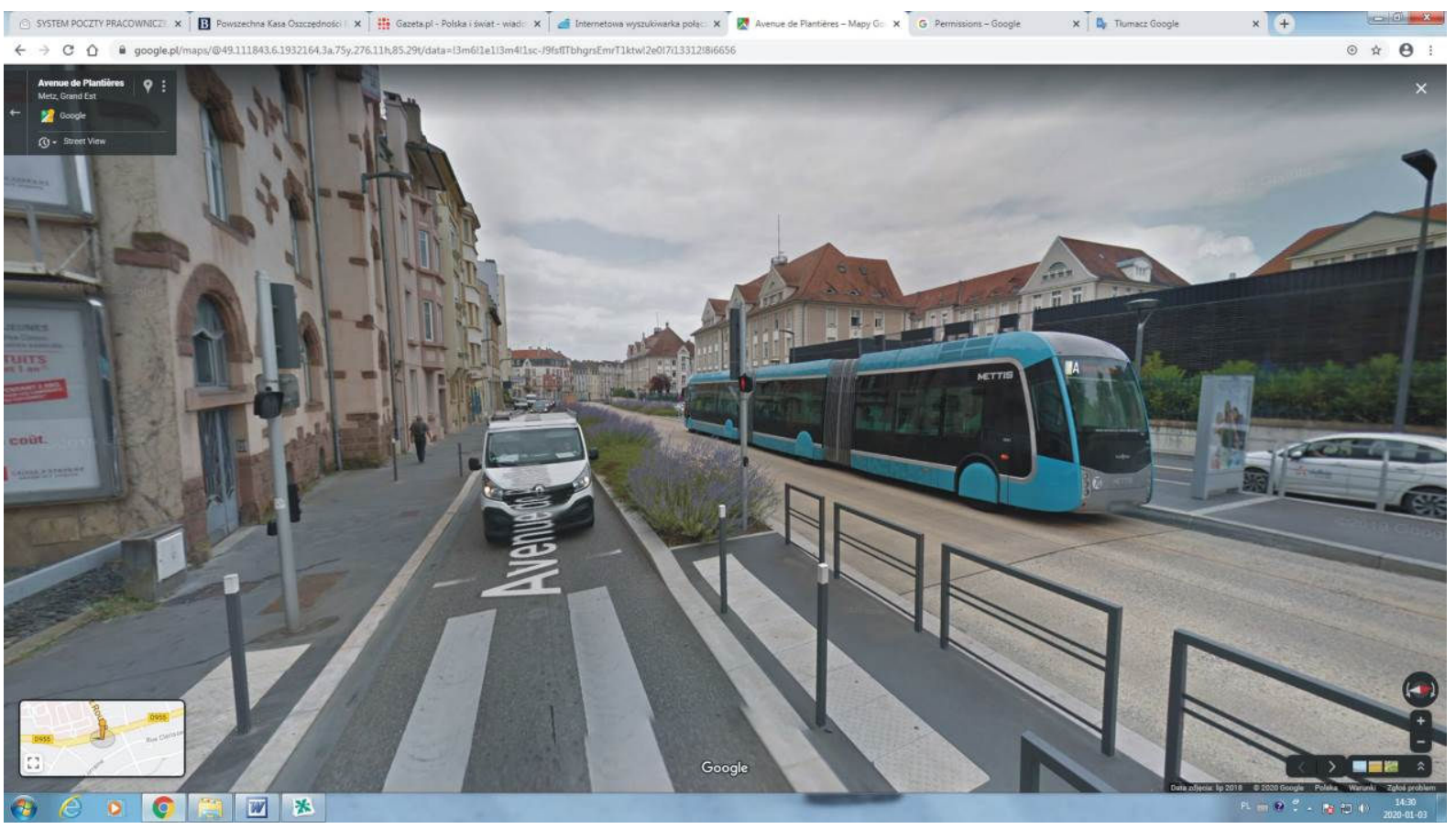

1. Mettis bus in Metz (street view)

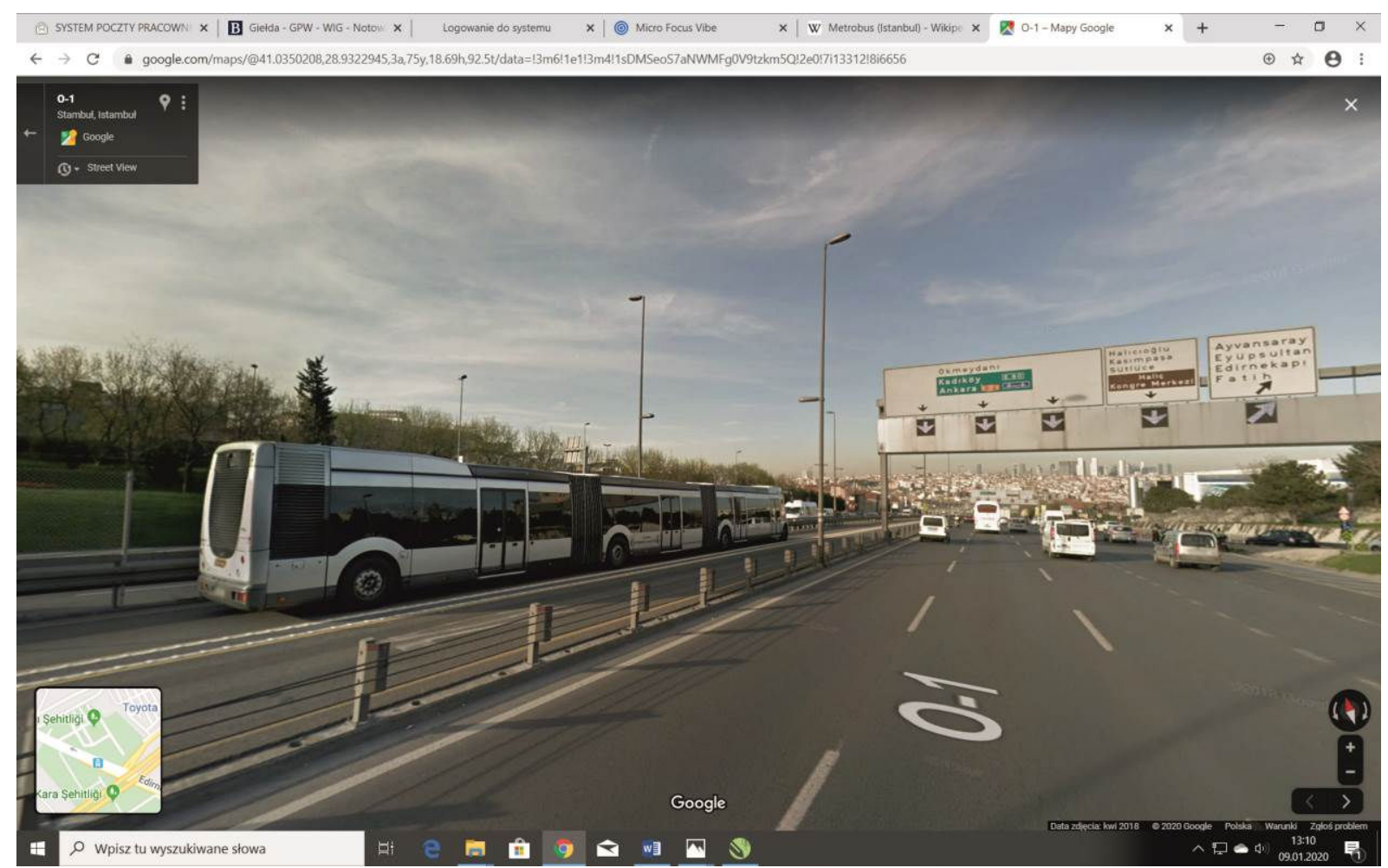

2. Phileas bus in Istanbul (street view)

Fully electric vehicles are another trend in the production of buses. For example, the articulated Volvo 7900 Electric is available in two lengths: 18 and 18.7 meters. In the first case, it can accommodate 150 passengers (Figure 3). It is powered by two $200 \mathrm{~kW}$ electric motors manufactured by Volvo. Batteries with a capacity of almost $400 \mathrm{kWh}$ were installed in 
it. Depending on the customer's needs, the Swedish manufacturer may enable charging both via fast charging stations on the route (OppCharge) and via stationary chargers [6].

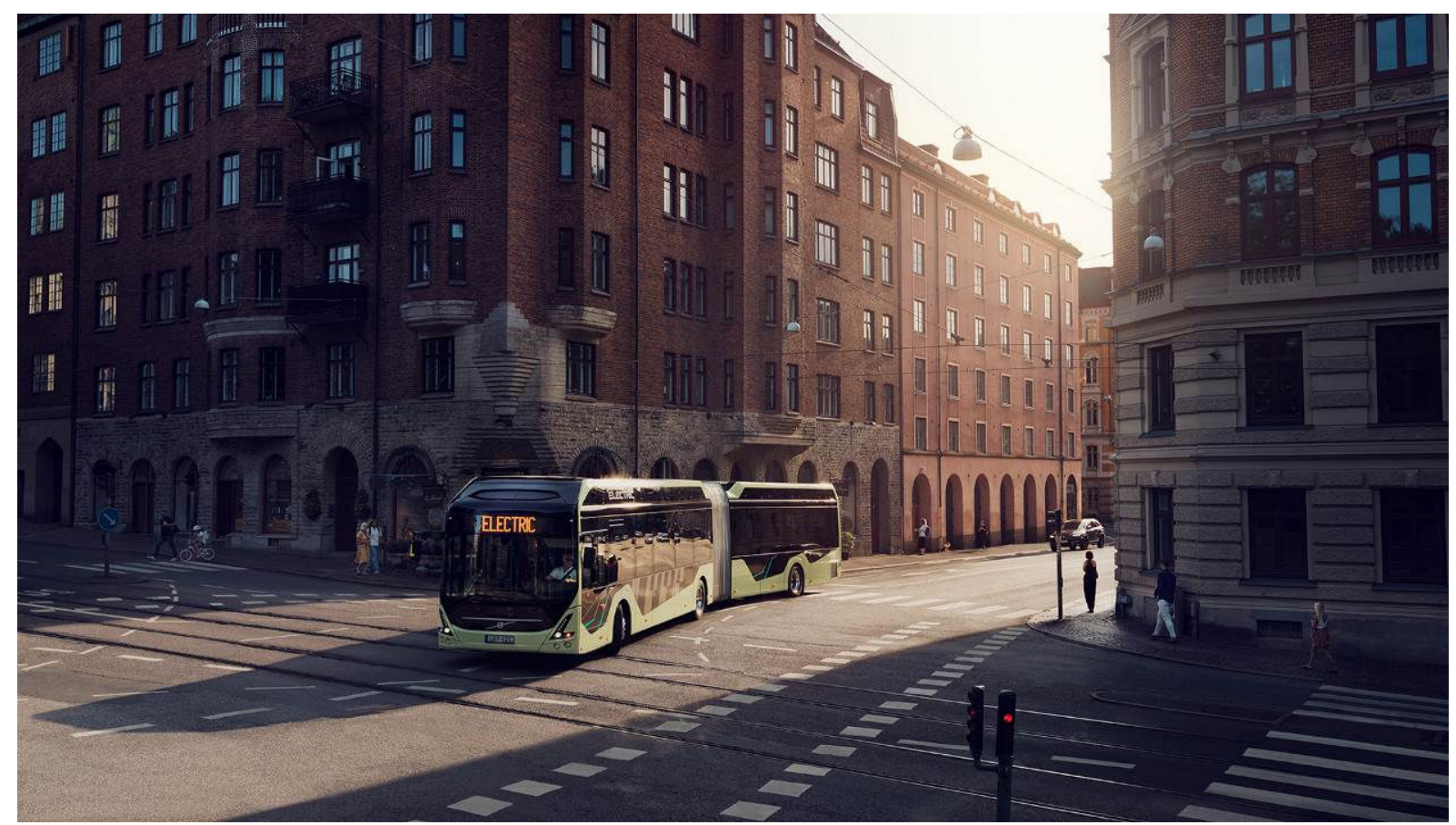

3. Volvo bus 7900 Electric ([6])

Unconventional versions of trams, for example, the solution called "tramway sur pneus" are interesting. "Rubber-wheeled" tram networks are popular especially in France (Translohr system developed by Lohr Industrie of France and now owned by the Alstom Transport consortium with Fonds Stratégique d'Investissement as "newTL". It is used in Paris area and in Clermont-Ferrand in France, Medellín, Colombia, Tianjin and Shanghai, China, and Venice-Mestre and Padua in Italy Map 4 shows the current state of tram routes in Ile-deFrance (Paris plus surroundings) Most of the lines shown were built in the 21st century ( See [1]). Lines: T5 and T6 operate as described above. Figure 5 shows a rubber-wheeled tram line T6 in Chatillon (Ile-de-France). Similar solutions have been used in other cities. In Caen since 2002 the guide rail serves as a return conductor for electricity (it runs with a diesel drive in the depot) In Nancy, since 2000, the overhead network on part of the route is of the trolleybus type (two conductors), the rest without the overhead network. 


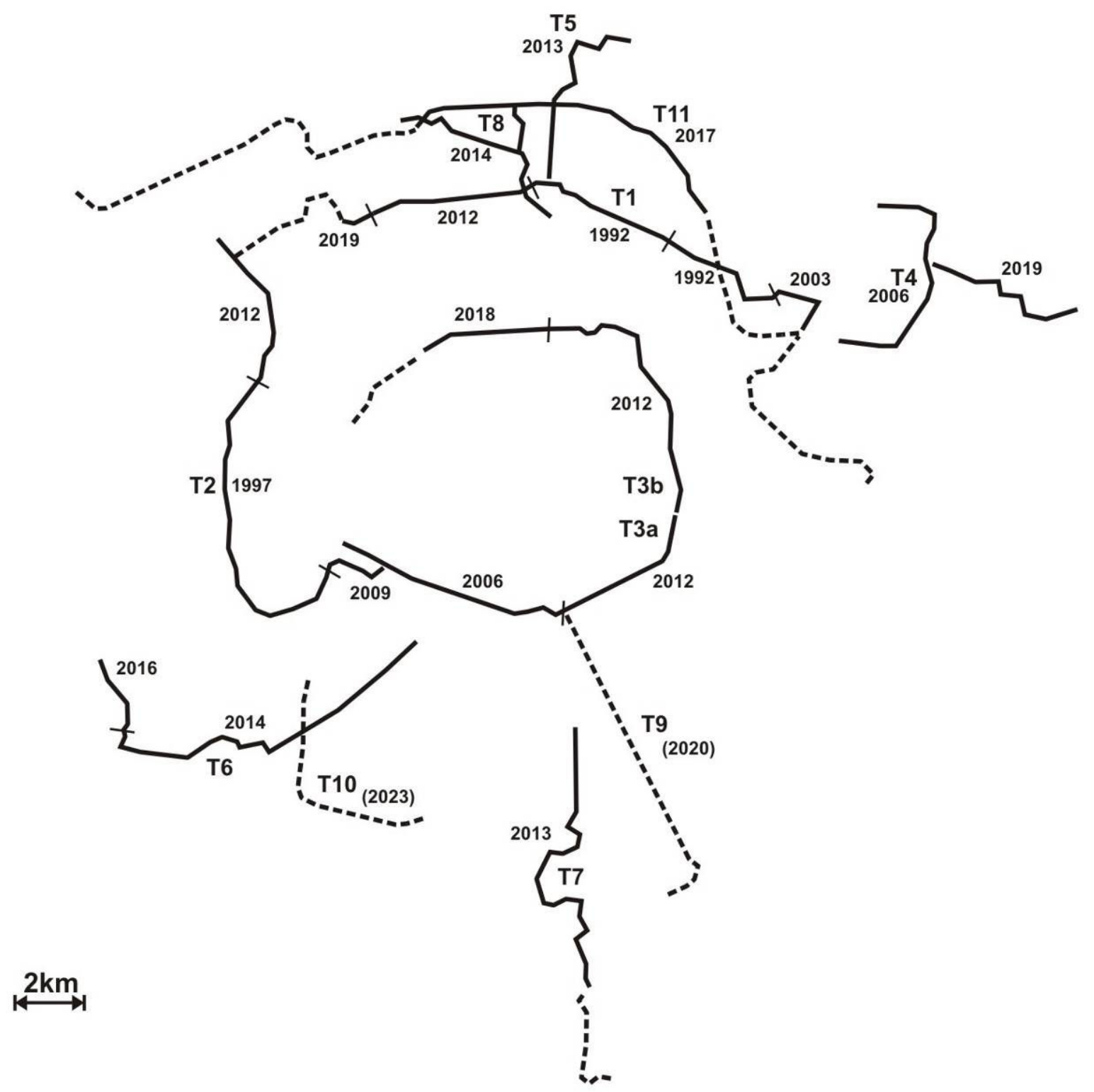

4. Tram routes in Ile de France 


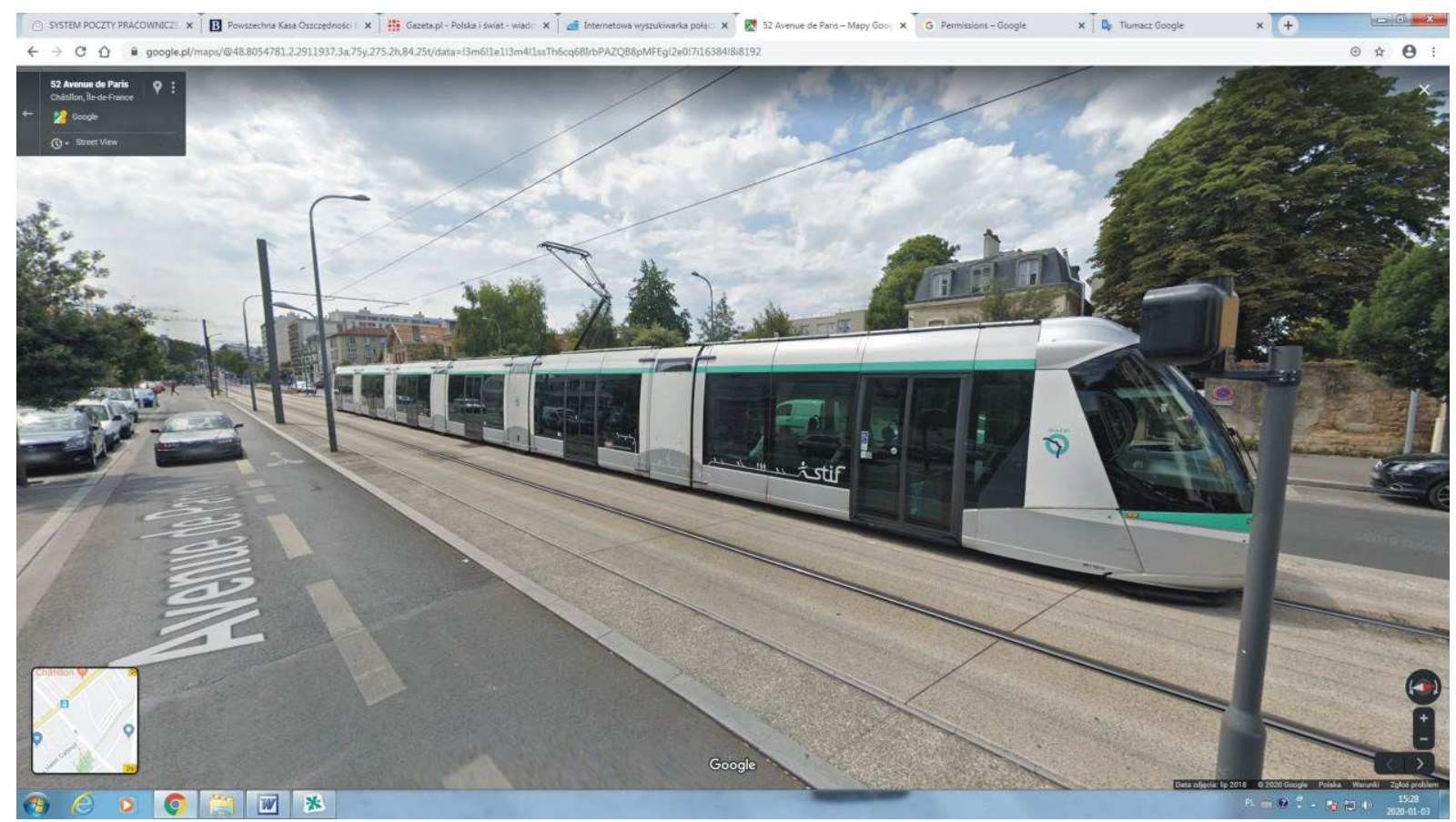

5. Translohr tram line T6, Chatillon (street view)

There is a problem of providing power when resigning from the traction network (which is especially attractive in the central, historic parts of cities). In Bordeaux, the city center tram does not use the overhead network. It is powered by the "ground" system (activated when the tram passes). This is Alstom's APS solution (Figure 6). The same is true for Nice, Orléans, Reims, and Tours. On the other hand, in Saragossa (Zaragoza), part of the tram route without the overhead contact line is powered by batteries (Figure 7).

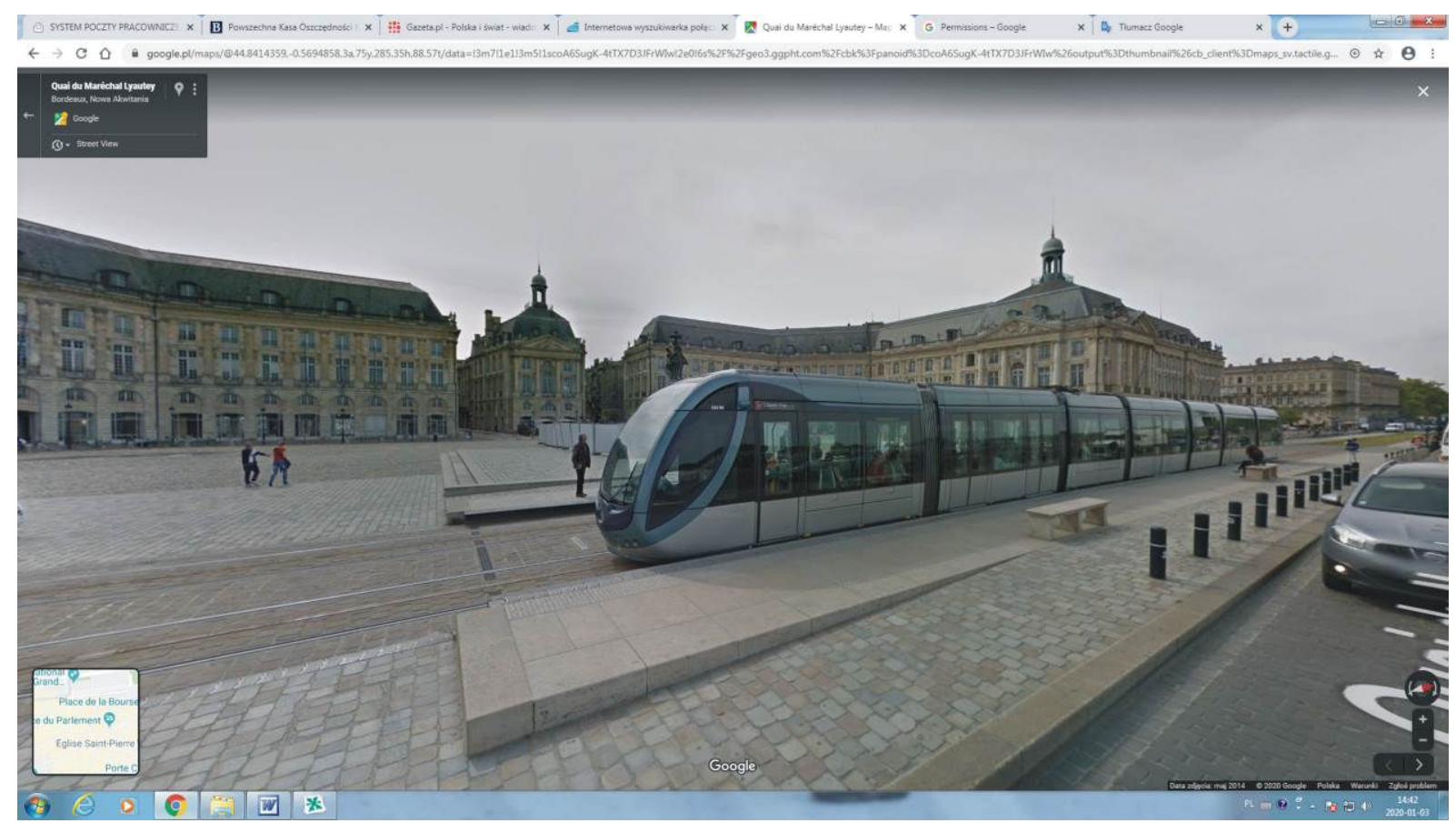

6. Catenary-free tram, Bordeaux (street view) 


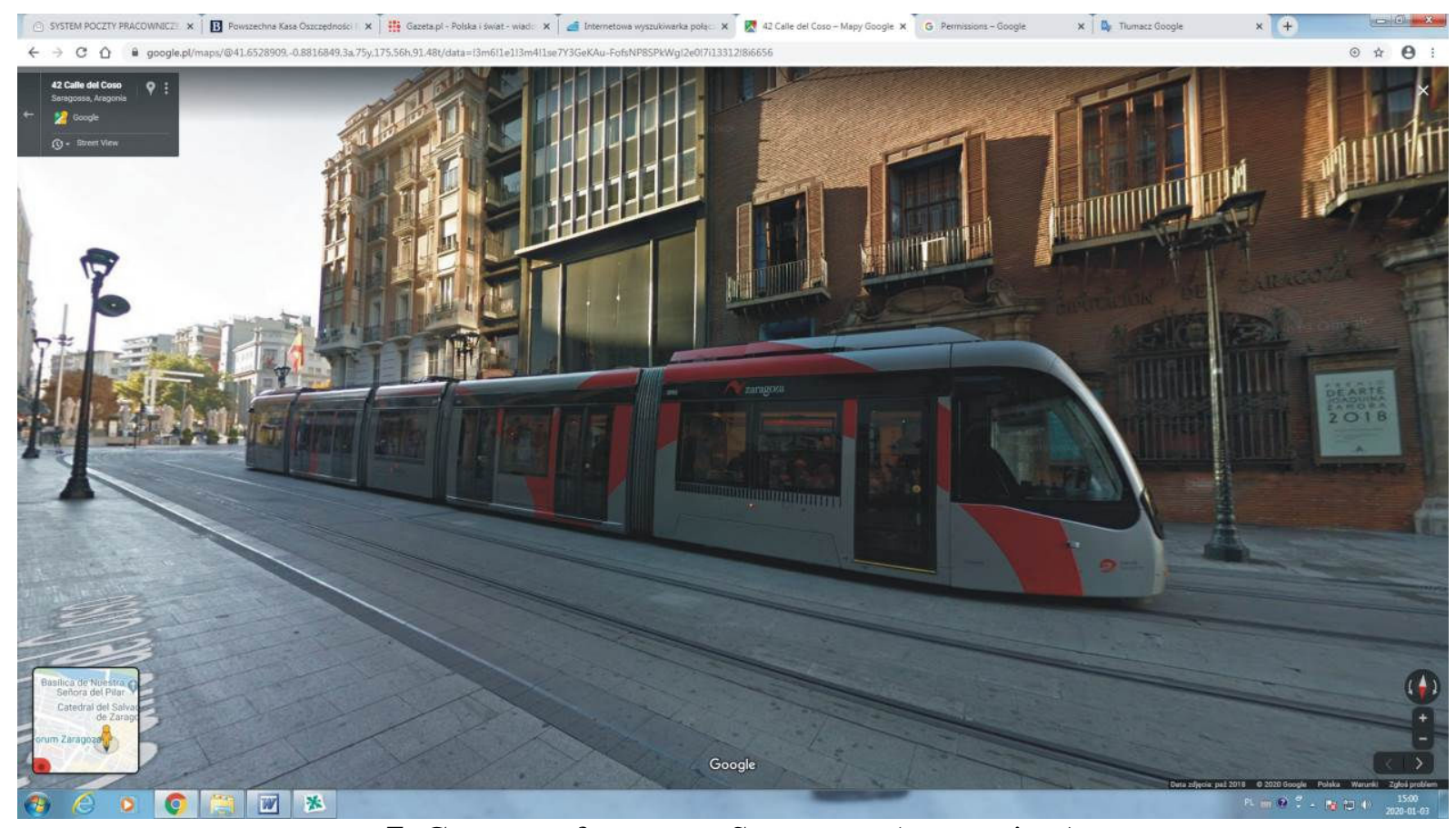

7. Catenary-free tram, Saragossa (street view)

Similar solutions also apply to trolleybuses. In Opava, part of the route runs without voltage from the overhead network, but then the diesel engine is running.

Castello (Spain) has the only trolleybus traction in this country, produced by Solaris (short versions), catenary-free section - a battery, in the downtown. Limoges uses (among others) long trolleybuses $(18.7 \mathrm{~m})$, three-axle Swiss made (Hess), called Swiss Trolley 4. There are, however, longer trolleybuses, for example by this manufacturer. Such longest trolleybuses called Light Tram are quite popular in Switzerland (Geneva, Lucerne, Zurich, St. Gallen).

In its trolleybuses, Solaris [7] offers three types of optional additional emergency driving systems. The first of them are traction batteries on the roof of the vehicle, which make it possible to cover from several to several dozen kilometers without traction power. Another solution is the use of a low-power diesel engine, which acts as a generator of electricity in sections without electric traction. The third solution is to use a hydrogen fuel cell as an electricity generator. It allows to travel up to $100 \mathrm{~km}$ without an overhead contact line with zero exhaust emissions. An example is the Solaris Trollino vehicle with the ability to cover part of the route (up to $5 \mathrm{~km}$ ) without being powered from the overhead network as part of the Lublin fleet. Trolleybuses of this type (Solaris Turbino Hybrid) are $18 \mathrm{~m}$ long and have three axles. So far, they are the longest of the trolleybuses operated in Poland. However, due to the market demand (Western Europe for the time being), a larger vehicle has already been developed. Work on the double-articulated version of the Solaris Urbino model has recently resulted in tests in Gdynia (Figure 8) and a presentation at the fair in Brussels (October 2019). 


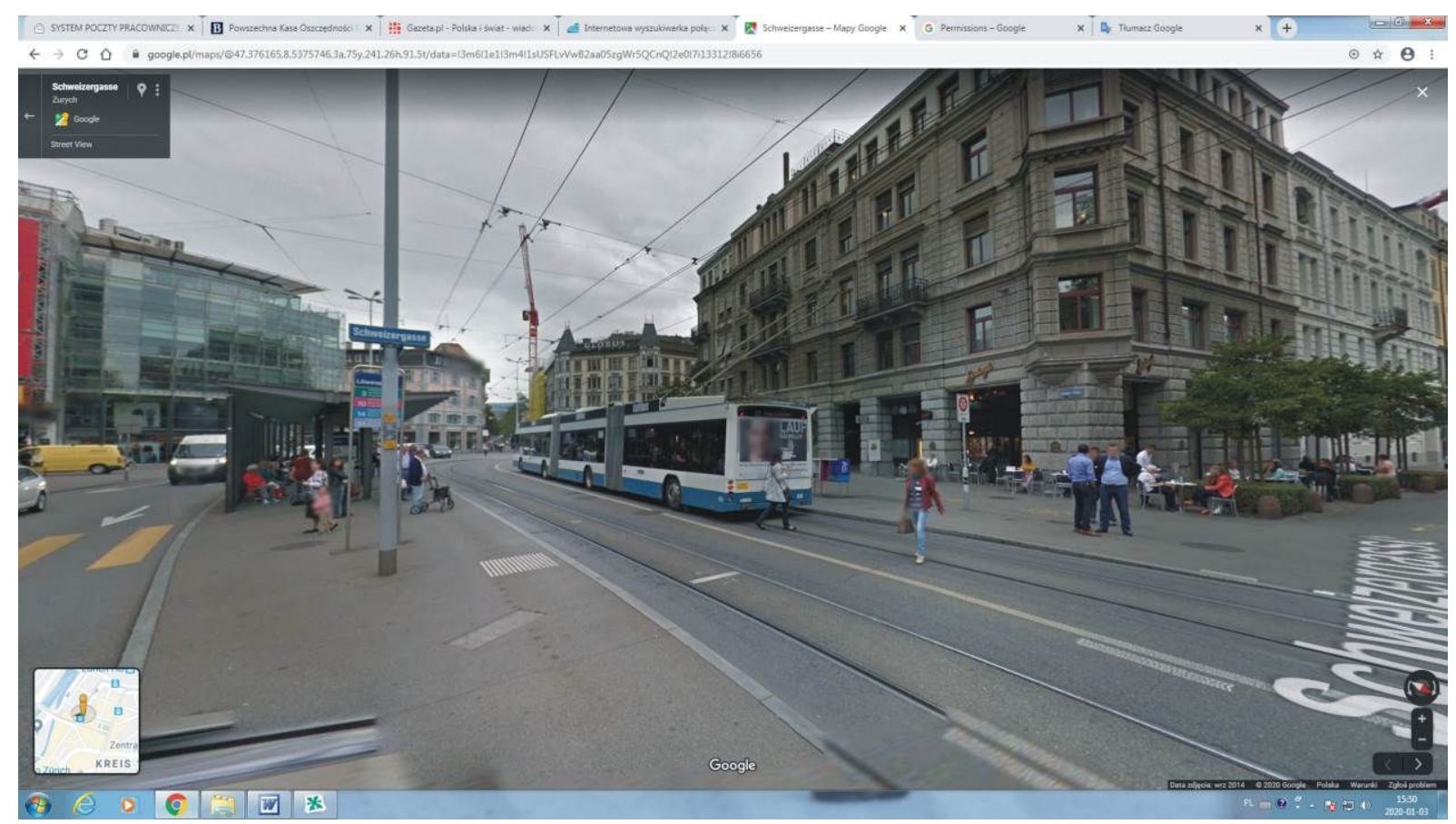

8. Solaris Trollino 24 during tests in Gdynia ([7]

\section{Defining innovation - requirements}

Article and the review of the latest solutions and trends, it is possible to propose a "slightly" innovative solution, probably the most effective in the current situation for many Polish cities, under the working name "AtTraction (AT)". It would be a rubber-wheeled, electrically powered vehicle with the ability to draw electricity from the overhead network or use batteries. The novelty consists in enabling energy consumption from the traction typical for trams (single-cable), which requires only (or not only?) The development of a method of transmitting current to the tram rail. It is not an unknown solution. At one time (in the 1930s), trolleybuses in Poznań used the tram network while moving around the depot (connection to the track as a turning rail with a bail).

The recommended length of the rolling stock is 24-25 meters (three joints, four axles), but it is also possible to use shorter units (classic articulation, $18 \mathrm{~m}$ ). Such rolling stock is currently in use (or in development) in the context of buses or trolleybuses. Modification of available vehicles in relation to the formulated requirements seems to be simple and possible to be performed in a short time. Such long vehicles should also be allowed for regular use on Polish roads (in the context of regulations).

The main advantage of the proposed solution is the possibility to use the existing and extensive tram networks (provided that the track is built) with the existing voltage systems. Network expansion can be realized in the form of AT, as an ad hoc or target solution. Apart from the financial aspect, extending the existing tram tracks may encounter specific barriers: steep driveways, junctions with railway tracks, lack of land reserve. In the simplest option, the continuation of the AT line running along a tram track can take place along an ordinary middle-class street (taking into account the dimensions of a double-articulated vehicle) on the basis of a bus (with the requirement to use a lane separated from traffic). Subsequently, it is possible to implement a separate route (roadway) in the TAT convention or with parameters appropriate for AT (for example, with the traction network). This shows the flexibility of network development variants and the introduction of new rolling stock. These advantages will be discussed in more detail on the example of the proposal for Wrocław. 
The operational advantages of "setting free" from the track are also important. In emergency situations or during renovation/modernization, it will be easy to change the route. Using the tram overhead line and autonomous batteries means savings in energy consumption and minimization of costs related to the construction of a power station.

\section{Application example}

An example of the introduction of AT vehicles and lines in Wrocław is presented, which can certainly inspire other cities (not only Poland). Wrocław is implementing an ambitious "Tram Program" [3], facing budget constraints and the need to launch main lines on selected routes "immediately". The ongoing tram investments will be completed within a few years. In contrast, long-term relations already face the need to improve transport. Therefore, for such relations it is proposed to introduce AT without prejudging its application in other relations. Map 9 shows the most densely populated areas compared to the existing tram network. It is not difficult to indicate the areas where the introduction of large-capacity city transport fleet is required.

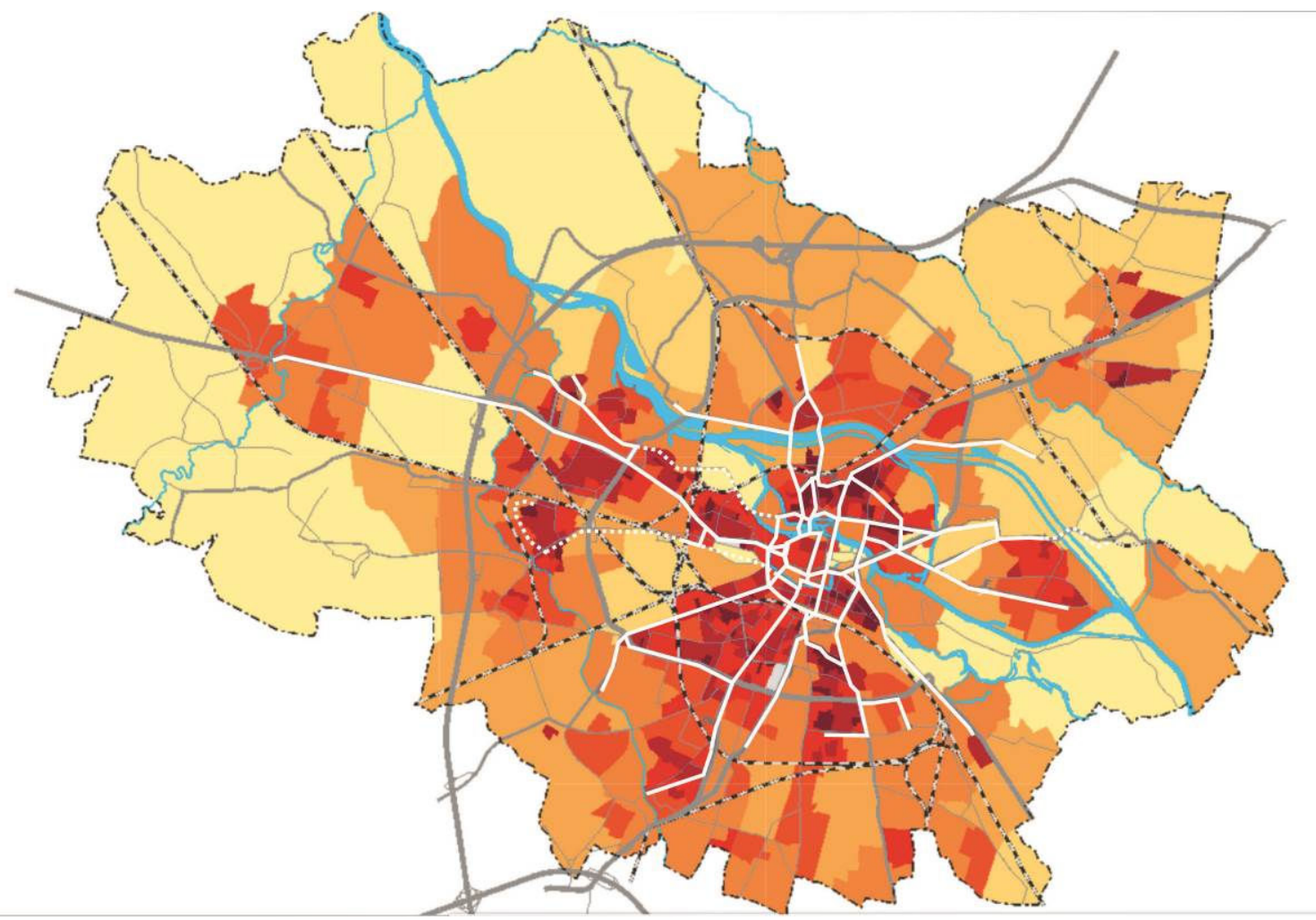

9. Wrocław's tram network compared to the population density (background map from [8])

He above postulate concerns, inter alia, the area of Psie Pole and Jagodno with their surroundings. The barriers to running trams there, apart from investment costs, are also intersections with railway lines. Hence, it is proposed to create an AT route connecting these areas. The multi-variant approach to the topic and the possible stages of implementation and further expansion of the system are shown on map 10. It also shows the proposed locations of back-up facilities (temporarily, z1, and ultimately, z2). Routing details in one of the variants are shown on maps $\mathbf{1 1}$ (southern part) and $\mathbf{1 2}$ (northern part). There were distinguished: sections with currently built-up tracks, tracks for development, and new sections in the AT standard (including some as recommended TAT). This represents the potential target course of AT routes. It is possible to stage and variant implementation as shown on map 10. Details 
of the above proposal, including the issues: frequency of running and the number of rolling stock will be the subject of further work.

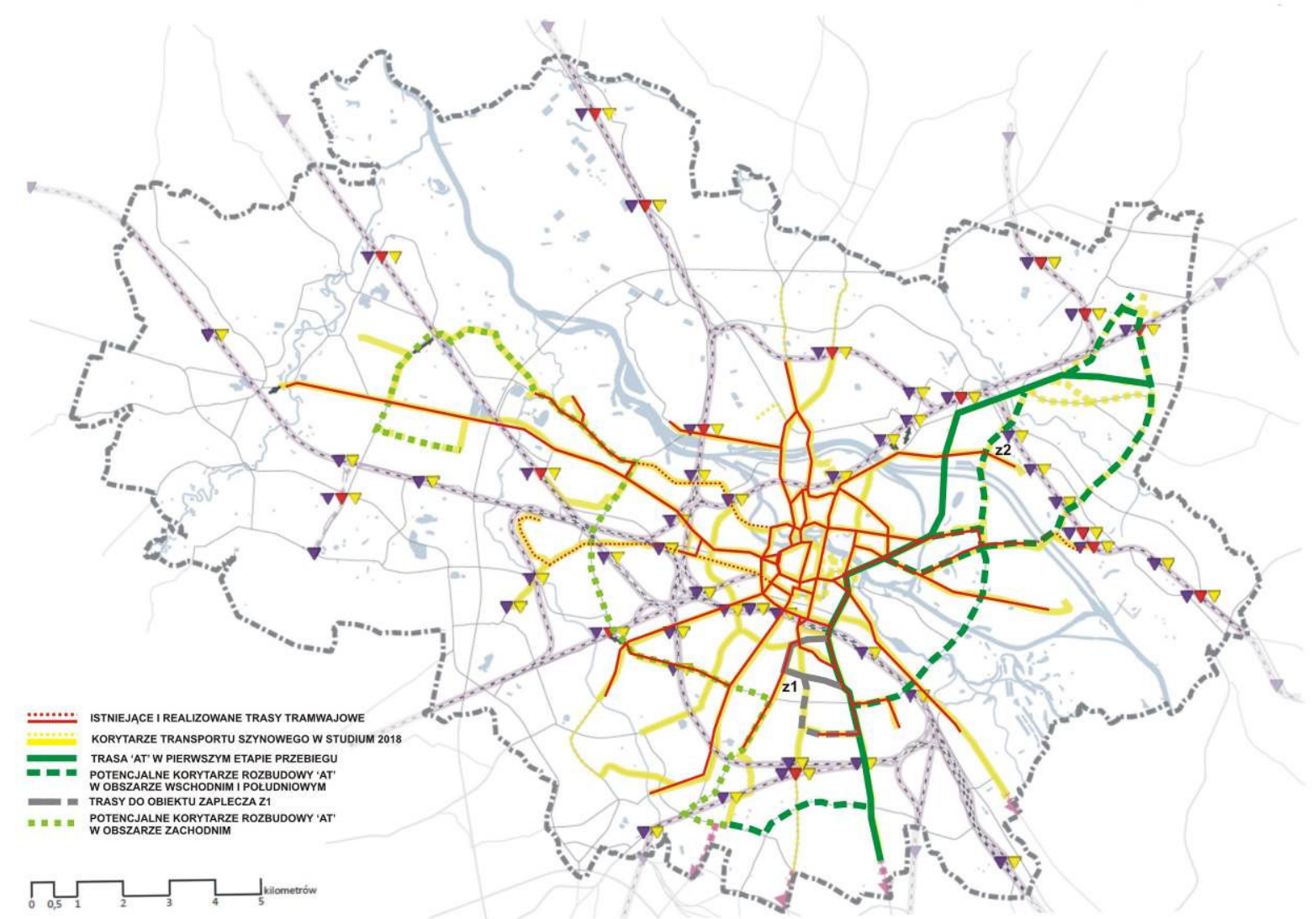

10. The proposal of introducing the AT system to Wrocław 


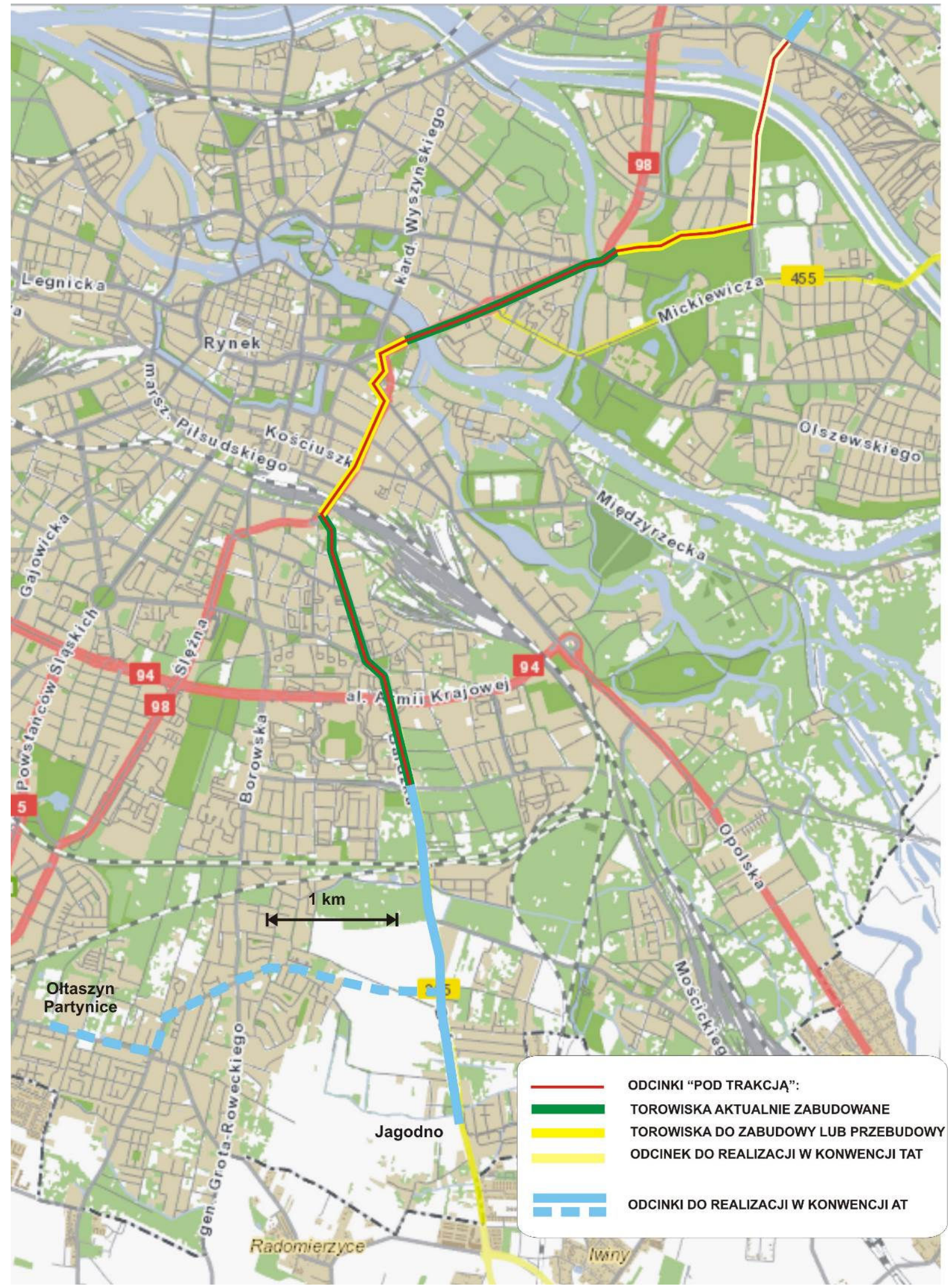

11. Details of one of the variants of the first AT route in Wrocław - the southern part (background map from [8]) 


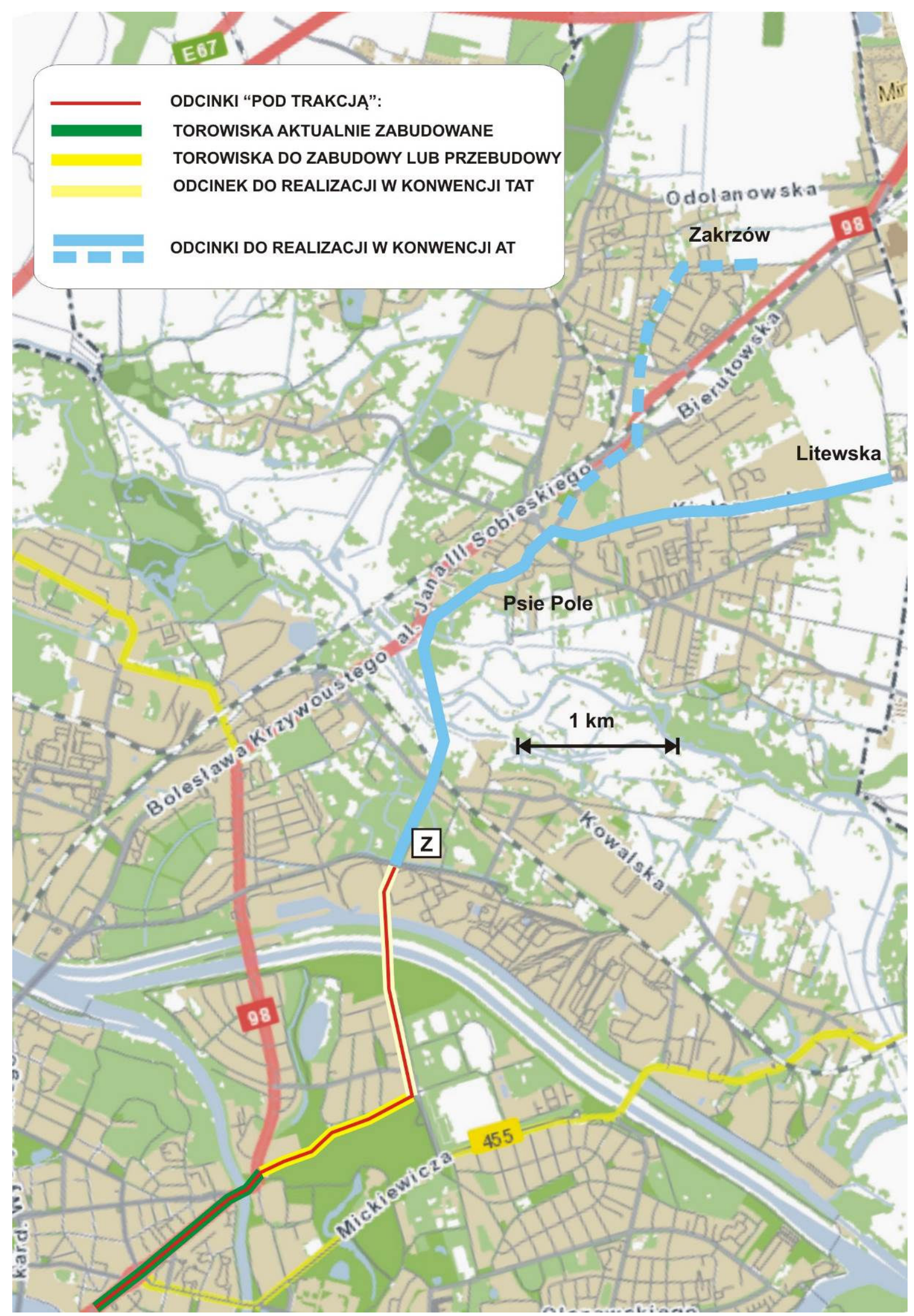

12. Details of one of the variants of the first AT route in Wrocław - the northern part (background map from [8]) 


\section{Summary}

It was proposed to introduce an innovative solution, but embedded in today's realities and based mostly on existing technologies. The implementation of the AT vehicle and system seems to be an attractive option, especially for Polish cities. Nevertheless, the available variants (classic tram, classic trolleybus, electric bus, etc.) should be compared in order to indicate the most advantageous option. It is desirable to conduct CBA (Cost-Benefit Analysis) or preliminary SW (Feasibility Studies). It is desirable to collaborate with leading rolling stock manufacturers with an invitation to develop a new experimental vehicle. Flexibility in introducing AT is also important. It can be a targeted or temporary solution. In a given agglomeration, routes to both of the above stages of operation can be selected.

\section{Source materials}

[1] Kruszyna M. „Powrót tramwajów do Londynu i Paryża” Transport Miejski 4/03

[2] Kruszyna M. „Klucz do planowania transportu publicznego w aglomeracji 30/6”, Studia nad rozwojem Dolnego Śląska nr 3 / 55 / 2014

[3] Kruszyna M. „Dlaczego tramwaj - rozważania na bazie Wrocławskiego Programu Tramwajowego" w: Polskie inwestycje transportowe : doświadczenia, badania i przyszłość, Poznań : Annały Inżynierii Ruchu i Planowania Transportu; t. 1 (XI), 2017

[4] „Renesans tramwaju w Polsce. Czy kłopoty branży budowlanej zagrożą planowanym inwestycjom?", raport ZGT TOR, Warszawa 2019.

[5] Ustawa o elektromobilności z dnia 11 stycznia 2018 r. „O elektromobilności i paliwach alternatywnych", Dz. U. z 2019 r. poz. 1124, 1495, 1527, 1716

[6] https://www.volvobuses.pl/pl-pl/our-offering/buses/volvo-7900-electric.html

[7] https://www.solarisbus.com/pl/pojazdy/napedy-zeroemisyjne/grupa-trollino

[8] www.geoportal.wroclaw.pl 